\title{
Akademik Çeviri Eğitimi ve Çeviri Bilgisi Alt Edlinci
}

\section{Academic Translation Education and Knowledge of Translation Sub-Competence}

\author{
Nilgin TANIŞ POLAT
}

${ }^{1}$ Doç. Dr., Ege Üniversitesi, Edebiyat Fakültesi, Mütercim ve Tercümanlık Bölümü, İzmir, Türkiye

ORCID: N.T.P. 0000-0002-6490-7395

\section{Corresponding author:}

Nilgin TANIŞ POLAT,

Ege Üniversitesi, Edebiyat Fakültesi,

Mütercim ve Tercümanlık Bölümü, Ege

Üniversitesi, İzmir, Türkiye

E-mail: nilgintanis@yahoo.com

Submitted: 08.07.2021

Revision Requested: 03.09.2021

Last Revision Received: 06.09.202

Accepted: 06.09.2021

Citation: Tanis Polat, N. (2021). Akademik çeviri eğitimi ve çeviri bilgisi alt edinci. Alman Dili ve Edebiyatı Dergisi - Studien zur deutschen Sprache und Literatur, 46, 143-168. https://doi.org/10.26650/sdsl2021-965635 öz

DeepL ve Google gibi çeviri hizmetleri, cep telefonlarında kullanılan mobil çeviri uygulamaları, çeviri yapabilen akıllı klavyeler, bilgisayarlarda kullanılan yazııımlar globalleşen dünyada bir ihtiyaca karşılık olarak üretilmiş, ancak bu yapay zekâ ürünleri henüz duygusal ve yaratıcı zekâsı olan insan çevirmenlerin yerini dolduramamış, aksine gelişmelerle birlikte birey olarak çevirmene atfedilen önem artmış ve akademik çeviri eğitimi içeriklerinin de gelişmelerle uyumlu olabilmesi bir gereksinim haline gelmiştir. Çalışmamız, bilimsel bilgilere dayalı bir çeviri anlayışının çeviri ürününü doğrudan etkilediği varsayımını temel alır. Çeviri edincini değerlendirecek parametreler karmaşık ve iç içedir ve çeviri bilgisi alt edinci, çeviri edincinin çok önemli bir bileşeni olmasına rağmen henüz yeterince incelenmemiştir (Eser, 2015). Bu nedenle araştırma kapsamında çeviri bilgisi alt edincini, özellikle çeviri anlayışını analiz etmek ve Almanca-Türkçe dil çiftine yönelik akademik çeviri eğitiminde uygulanabilecek bir ölçek oluşturulması amaçlanmıştır. Araştırmanın kavramları, çeviri edinci edinimi süreci üzerinde derinlikli araştırmalar yürüten PACTE Grubu'nun Researching Translation Competence (2017) isimli eserine dayanmakla birlikte, çalışma kapsamında ayrıca çeviri anlayışı kavramı belirlenmiş ve tanımlanmıştır. Bununla birlikte Ege Üniversitesi Almanca Mütercim-Tercümanlık Bölümü'nde ve Ege Üniversitesi Alman Dili ve Edebiyatı Bölümü'nde eğitim alan öğrencilerin çeviri anlayışları gözlemlenmiş, gözlemlerden hareketle çeviri bilgisi alt edincine odaklanan ve katılımcıların çeviri edincini devingen-duruk kavramları (Albir, 2017; Albir et al. 2020) üzerinden değerlendiren bir anket hazırlanmış, anket verileri IBM SPSS Statistics 25 programılla analiz edilerek çeviri eğitimine yönelik çıkarımlar irdelenmiştir. Eylem araştırması desenine dayalı araştırma yaklaşımıyla yürütülen çalışma kapsamında akademik çeviri eğitimine ilişkin önemli bir sorunsal belirlenmiş ve uygulamada kullanılabilecek bir ölçek geliştirilmiştir.

Anahtar Kelimeler: Çeviri bilgisi alt edinci, çeviri edinci, çeviri anlayışı, PACTE, akademik çeviri eğitimi

\section{ABSTRACT (ENGLISH)}

Translation apps available in the market, such as DeepL and Google, smart keyboards capable of translating and related software have been produced to meet the current needs in the world. Yet the artificial intelligence has not replaced the human translator with emotional and creative intelligence. On the contrary, the 
importance of translators as individuals has grown and the content of the academic translator training is to be altered accordingly. This study is based on the assumption that the translation approach dependent on the scientific knowledge directly shapes the translation as a product. The parameters to evaluate translation are complex and interwoven. Although the translation sub-competence is an elementary part of the translation competence, it is still underresearched. (Eser, 2015). Thus, this article aims to analyze translation sub-competence with a specific focus on translation approach and to construct a scale to be applied in the German-Turkish language pair. The conceptual framework is based on Researching Translation Competence (2017) by the PACTE team which conducts advanced research on the acquisition of translation competence. The translation approach of undergraduates of the Translation and Interpreting Studies B.A. Program and the German Language and Literature B.A. Program at Ege University have been observed, a survey focusing on the sub-competence of translation which evaluates the translation competence of the participants pursuant to the concepts of dynamic - static (Albir, 2017; Albir et al. 2020) accordingly, the data acquired has been analyzed with IBM SPSS Statistics 25 and the deductions have been examined. A pivotal problem in translator training has been detected and a scale to be applied has been developed within the scope of the study which is based on an activity research pattern.

Keywords: Knowledge of translation sub-competence, translation competence, translation concept, PACTE, academic translation education

\section{EXTENDED ABSTRACT}

Translation apps available in the market, such as DeepL and Google, smart keyboards capable of translating and related software have been produced to meet the current needs in the world. Yet the artificial intelligence has not replaced the human translator with emotional and creative intelligence. On the contrary, the importance of translators as individuals has grown and the content of the academic translator training is to be altered accordingly. This study is based on the assumption that the translation approach dependent on the scientific knowledge directly shapes the translation as a product. The parameters to evaluate translation are complex and interwoven. Although the translation sub-competence is an elementary part of the translation competence, it is still underresearched (Eser 2015). Thus, this article aims to analyze translation subcompetence with a specific focus on the translation approach and to construct a scale to be applied in the German-Turkish language pair. The conceptual framework is based on Researching Translation Competence by the PACTE Group (2017) which conducts advanced research on the acquisition of translation competence. The translation approach of undergraduates of the Translation and Interpreting Studies B.A. Program and the German Language and Literature B.A. Program at Ege University have been observed, a survey focusing on the sub-competence of translation which evaluates the translation competence of the participants pursuant to the concepts of dynamic - static (Hurtado Albir 2017, Hurtado Albir vd. 2020) accordingly, the data acquired has been analyzed with IBM SPSS Statistics 25 and the deductions have been examined. A pivotal problem in translator training has been detected and a scale to be applied has been developed within the scope of the study which is based on activity research pattern. 
Test types that are based on the translation of source texts into the target language on grammar and vocabulary basis that students are familiar with during their preparation process for the university entrance exam are found to be effective in their understanding of translation, and the effects thereof on their translation practice have been examined. It was observed that students assumed a presumption that the static approach is the sole and ideal approach in translation, and thus made a habit of doing static translation in translation practice as well.

This study revealed that the static approach that induces the candidate translators' fear of digressing from the source text and supports their propensity for using a dictionary precluded them from producing texts in the target language in accordance with the text norms and caused them to use smaller translation units as a basis, compared to experienced translators. The tendency of the students to focus on syntactic forms and word units, which is frequently observed in the semi-professional translators, also prevents them from focusing on content integrity.

This article concluded that the translation approach of undergraduates in German Translation and Interpreting Studies is more dynamic than that of undergraduates in German Language and Literature; German Language and Literature undergraduates have a higher coherence coefficient of knowledge of translation. Although the translation knowledge competence of undergraduates in the German Translation and Interpreting Studies department is higher than that of the undergraduates in the German Language and Literature department, it is interesting to note that undergraduates who intend to be translators in the future have a lower level of translation knowledge. The difference between the undergraduates is thought to stem from the courses they took in the first year. The fact that undergraduates of German Language and Literature desire to work as translators after graduation more than undergraduates of German Translation and Interpreting Studies and that they are of the opinion that the education they received is qualified for being a translator stands out as a striking indicator.

This scale can be used by the instructors who provide translation training for the German-Turkish language pair in the departments of German Translation-Interpretation / Translation Studies, German Language and Literature and German Language Education. In this way, students can question their presumption. How the translation is created, what the translation units are, the methods that can be used, the types of problems to be encountered and the professional requirements can be examined in the lessons through 
the scale. The learning process can also be effectively supported with this scale. Using the scale at the beginning of the academic translation education will increase the awareness of the student and enable him/her to think multi-dimensionally. Thus, it will be easier to find effective solutions. In academic translation education, doing translation exercises from grammatically easy texts to difficult texts will not improve students' translation competence much. Presenting this scale in lessons in order to improve students' translation knowledge skills will be an important step for the student's development. Along with the scale, basic information about acquiring translation skills can be given; the differences between static and dynamic translation approaches can be examined in a more comprehensive way through rich points and a discussion environment can be created on the scale. In this way, the subject can be discussed in detail and a stimulus can be created for students to question their own approaches in this way. 


\section{Giriş}

Türkiye'de çevirmen adaylarına yönelik eğitim veren Mütercim-Tercümanlık ve Çeviribilim gibi bölümlerin yanı sıra Yabancı Dil Öğretmenliği ve Filoloji bölümlerinde de çeviri dersleri sunulmaktadır.' Ancak yalnızca Mütercim-Tercümanlık ve Çeviribilim bölümlerinde "piyasanın uzman çevirmen gereksinimini karşılamak" öncelikli hedef olduğundan özellikle bu bölümlerde kapsamlı bir akademik çeviri eğitimi verilir (Tapan/ Kuruyazıcı, 2020, s. 229). Akademik çeviri eğitiminde ${ }^{2}$ yabancı dil edincinin önemi yadsınamaz, ancak iki dili çok iyi bilen bir bireyin çok iyi çeviri yapacağı veya dil edincinin geliştirilmesinin çeviri edincini de geliştireceği yanılgısı yaygındır. Bu durum çeviri alanında eğitim görmeyi hedefleyen, hatta akademik çeviri eğitimi alan öğrenciler için de geçerlidir. Çoğu öğrenci dil edinci ile çeviri edinci arasındaki ayrımın farkında değildir. Bu eksiklik öğrencilerin kendilerini geliştirmelerine ve çevirmen olarak amaçlanan noktalara gelmelerine engel olmaktadır. Çeviri eğitimi veren öğretim elemanları da akademik eğitime yeni başlayan öğrencilerin belirli değer ve davranış kalıplarına sıkıştığının farkındadır. Öğrenciler yerleşik ön kabulleri sorgulamaya yönelik kuramsal yaklaşımlardan yeterli derecede faydalanamaz ve uygulamada yöntem sorunu ile karşı karşıya kalırlar. Öğrencilerin çeviri ve yabancı dil edincini birbirinden bağımsız olarak ölçebilen bir ortam ve yöntem bulunmadığından öğretim elemanları da öğrencilerin davranış kalıplarını kırmakta ve yeni bir çeviri anlayışı oluşturmakta zorlanır ve çeviri edincini, ilgili yetileri ölçmeye yönelik özellikler taşımayan metinler üzerinden değerlendirmeye devam ederler. Hâlbuki seçilen metinlerin niteliğinden dolayı yapılan çeviri üzerinden, kaynak metnin gerçekten anlaşılıp anlaşılmadığı, aktarımın yeterli olup olmadığı, eksikliğin ne olduğu, yanlışın nereden kaynaklandığı çoğunlukla fark edilmez ve çeviri edinci tam anlamıyla ölçülemez. Çeviri edincinin bu nedenle tüm yönleriyle ele alınması ve eleştirel bir bakış açısı için gerekli etmenlerin ortaya konulması bir gerekliliktir.

\subsection{Araştırma Konusu ve Amacı}

Çeviri sürecini aksatan etmenler arasında dil edinci yetersizliği yanında, çeviri edinci yetersizliği de önemli bir sorun oluşturur, oysa bu ikinci etmen öğrenciler tarafından çoğu kez göz ardı edilir. Akademik çeviri eğitimi veren öğretim elemanlarının öğrencilerin hazır

1 Çeviri dersi sunan bölümlerin çevirmen yetiştirip yetiştirmediği konusundaki tartışmalara ilişkin bkz. Kurultay $(1998$, s. 307).

2 Durukan (2018, s. 32) "çeviri eğitimi" ve "çeviri öğretimi" ifadeleri arasındaki ayrıma dikkat çekmekte ve "akademik düzlemde hedef belirleme ve çeviri edincinin akademik düzlemde nasıl ölçülebileceğine ilişkin soruların yanıtlarının bilimsel verilerle temellendirilmeye çalışıldığı bir çalışmada çeviri öğretimi kavramının kullanılması gerektiği çıkarımı”nı yapmaktadır. Ancak çalışmamızda alan yazında hâkim olan geleneksel kullanıma bağlı kalınarak "çeviri eğitimi" ifadesi öncüllenmiştir. 
bulunuşluğuna yönelik bir seviye tespit sınavı yapması halinde, öğrenciler kendi eksiklerine bilinçli bir şekilde yaklaşacak ve ilgili açığı gidermeye yönelik daha etkin bir öğrenme süreci yaşayacaklardır. Öğretim elemanlarına da farkındalığı artan öğrencilerle daha verimli çalışmalar yapmaya elverişli bir zemin sağlanmış olacaktır. Çalışmanın genel amacı bu konuya dikkat çekmektir. Araştırmanın temel hedefi ise akademik çeviri eğitiminde çeviri edincini etkileyen etmenlere ışık tutmak, özellikle çeviri bilgisi alt edincini analiz etmek ve bu çerçevede öğrencilerin seviyesini saptamaya yönelik bir ölçek geliştirmektir.

Çalışma şu varsayımlara dayanmaktadır:

- Akademik çeviri eğitimi almayan, ancak yabancı dil bilen bireylerde çeviri edincini belirleyen ön kabuller (çeviriyle ilgili benimsenen tutum ve davranışlar) vardır.

- Bu ön kabuller çeviri edincinin bir alt edinci olan çeviri bilgisi alt edincini etkilemektedir.

· Üniversite sınavına dil puan türünden hazırlanan bireylerin ön kabulleri ÖSYM tarafından yapılan sınavlarla pekiştirilmektedir.

- Kapsamlı bir akademik çeviri eğitimi almayan bireylerde bulunan ön kabuller çeviri edincini geciktirmektedir.

Çalışmada belirtilen varsayımlar doğrultusunda akademik çeviri eğitiminin verimli ve etkili olabilmesi düşüncesinden hareketle şu sorular araştırılacaktır:

- Çeviri edincinin bir alt edinci olan çeviri bilgisi alt edinci nedir?

- Çeviri edincini olumlu/ olumsuz etkileyen etmenler nelerdir?

- Kapsamlı bir akademik çeviri eğitimi almamış olan öğrencilerde çeviri edincini etkileyen ön kabuller nelerdir?

· Çeviri edincini olumsuz etkileyen ön kabuller varsa bu etki nasıl önlenebilir?

- Çeviri edincini olumsuz etkileyen ön kabuller Mütercim-Tercümanlık/ Çeviribilim ve Filoloji bölümleri öğrencileri arasında farklılık göstermekte midir?

- Akademik çeviri eğitimini destekleyecek geniş çaplı bir ölçek oluşturulabilir mi?

- Çeviri edincini etkileyen etmenlere yönelik bir ölçeğin hazırlanması mümkünse, bu ölçek nasıl olmalıdır?

Akademik çeviri eğitimini geliştirmeye yönelik bir çalışma yapmak adına yukarıda belirtilen varsayımlardan hareketle çalışma kapsamında geliştirilen ölçek, araştırmanın en somut çıktısıdır. Bu çalışma ile ayrıca Almanca-Türkçe dil çiftine yönelik çeviri eğitimi 
veren öğretim elemanlarına, öğrenme sürecini etkileyen değişkenler çerçevesinde örnek bir uygulama önerilecek, Almanca Mütercim-Tercümanlık/ Çeviribilim, Alman Dili ve Edebiyatı ve Alman Dili Eğitimi bölümlerinin çeviri derslerinde uygulanabilecek ortak bir model oluşturulacaktır.

\subsection{Araştırmanın Çerçevesi ve Yöntem}

Teknolojinin gelişmesiyle birlikte çeviri eğitimini geliştirmeye yönelik çalışmalar zaman içinde artsa da çeviri edincine yönelik deneysel olarak geçerliliği araştırılmış çalışmaların azlığı dikkat çekicidir. Bu bağlamda Alves/ Gonçalves (2007), Göpferich (2009) ve PACTE (2000/2003/2017)'nin çalışmaları dikkate değerdir. Türkiye'de konuyla ilgili yapılan çalışmalar içinde de özellikle Birkan-Baydan'nın (2013) çeviri ve çevirmenlik edinci kavramlarını açımladığı ve bir farkındalık uygulaması önerdiği çalışması kayda değerdir. ${ }^{3}$ Almanca-Türkçe dil çiftine yönelik çeviri edincine odaklanan eserler içerisinde ise özellikle Öncü (2016) ve Akdağ (2019)'ın çalışmaları dikkat çekicidir.

Bu çalışma, anılanlardan farklı olarak bir alt edinç türü olan çeviri bilgisi alt edincine odaklanmakta ve bu alt edince ilişkin akademik çeviri eğitimini geliştirmeye yönelik somut bir araştırma olmasıyla öncekilerden ayrılmaktadır. Bununla birlikte yazılı çeviri için gerekli çeviri edincinden yola çıkılmaktadır, çünkü yazılı çeviri tarihsel gelişimi içerisinde olduğu gibi günümüzde de en yaygın yapılan çeviri türüdür (Yazıcl, 2007, s. 8-9). Çeviri edincini değerlendirecek parametreler karmaşıktır ve iç içe geçmiştir, aralarındaki etkileşimi belirlemek zordur. Ayrıca çevirmen adaylarının bakış açılarını anlamaya yönelik verinin, derinliği içinde betimlenmesi ve yorumlanması gerekmektedir. Bu bağlamda araştırmanın amacına ulaşabilmesi adına nitel araştırma yöntemlerinden faydalanılmış ve eylem araştırması desenine (Yıldırım/ Şimşek, 2016, s. 55) dayalı bir araştırma yaklaşımı benimsenmiştir. Bu çerçevede Yükseköğretim Kurumları Sınavı Yabancı Dil Testi (YDS) sonuçlarına göre üniversiteye giriş hakkı kazanan, Ege Üniversitesi Almanca MütercimTercümanlık Bölümü'nde ve Ege Üniversitesi Alman Dili ve Edebiyatı Bölümü'nde eğitim alan öğrencilerin çeviri edinçleri gözlemlenmiş, gözlemlerden hareketle çeviri bilgisi alt edincine odaklanan bir anket ${ }^{4}$ hazırlanmış, anket verileri analiz edilerek gerçekleşen çalışma ile çeviri eğitimine yönelik çıkarımları irdelenmiştir.

3 Çevirmen edinci ve çeviri edinci konularına ilişkin yapılan diğer önemli çalışmalar için bkz. Eser (2015). Konuya farklı yaklaşımlar içeren güncel araştırmalar için bkz. Akalın (2016), Durukan/ Çelikay (2018), Haldan (2021), Korkmaz (2019) ve Şevik/ Gündoğdu (2018).

4 Ek bölümünde yer alan anket için Ege Üniversitesi Sosyal ve Beşeri Bilimler Bilimsel Araştırma ve Yayın Etiği Kurulunun onayı alınmıştır. 
Üç bölümden oluşan anketin ilk bölümü katılımcıların kişisel bilgilerine odaklanmaktadır. Anketin ikinci bölümünde yer alan çeviri bilgisi alt edincini ölçen kısım, Researching Translation Competence by PACTE Group (2017) başlıklı eserde yayınlanan "Knowledge of Translation Questionnaire'"in Türkçeye çevrilmiş halidir. ${ }^{5}$ Katılımcıların çeviri edinci bu sorulara verilen yanıtlar üzerinden "devingen-duruk" kavramları (Hurtado Albir, 2017; Hurtado Albir et al., 2020) kapsamında değerlendirilmiştir. Katılımcıların devingen ve duruk skorları hesaplandıktan sonra, devingen ya da duruk ölçütlerinin tutarlılığı da her katılımcı için hesaplanmıştır. Anketin üçüncü bölümünde ise katılımcıların çeviri bilgisi alt edinçlerini nasıl kullandıklarına ilişkin araştırma yapabilmek adına bir uygulamaya da yer verilmiştir. Oluşturulan metin, "rich points" (Nord, 2006/2014)6 çerçevesinde çeviri seçenekleri sunacak şekilde tasarlanmış ve katılımcının çeviri yönteminin bu "noktalarda" devingen veya duruk olup olmadığı sınanmıştır. Kabul edilebilirlik skalası (Hurtado Albir, 2017) üzerinden yapılan ölçüm ile anket bu biçimde hem katılımcıların çeviri anlayışını hem de uygulamada benimsenen yaklaşımı değerlendirilebilmiştir. Bu çerçevede anketin özelliği, öğrencinin çeviri bilgisi alt edincini ölçmeye yarayan, hangi güdümleri başarıyla kullanabildiğini ve hangilerinde başarısız kaldığını gösteren bir yapıda tasarlanmış olmasıdır. Öğretim üyelerinin öğrencilerde bir farkındalık aracı olarak da kullanabileceği bu anket ile aynı zamanda öğrencilerde bir tür öz eleştirel bakışın yerleşmesini sağlayan bir ölçek de oluşturulabilmiştir.

\section{2. Çeviri Edinci}

Çeviri edinci, duruma göre etkin ve yerinde kararlar alarak bütüncül bir yaklaşımla çeviri yapabilmek amacıyla edinilen bilgi ve becerilerin tümüdür.

Çeviri edincinin bileşenlerinin sayıca fazla, karmaşık ve iç içe geçen bir yapıda olması nedeniyle içinde yer alan bileşenlerin bütüne etkisini ve birbirleriyle olan etkileşimlerini anlamak çeviri edincine ilişkin yapılacak her türlü analiz için çok önemlidir. Çeviri edinci "bir edinçler bütünü" (Esen-Eruz 2008, s. 219) olduğu için, farklı alt edinçlere odaklanan çok sayıda bilim insanı vardır. Barselona Otonom Üniversitesi'nde bir araştırma grubu olan PACTE'nin öncelikli amacı, akademik çeviri eğitimini geliştirmek adına güvenilir ölçekler oluşturarak çeviri sürecine ve çeviri edincine bilişsel açıdan ışık tutmaktır. 20 yıllık araştırmalarının güncel özetini sundukları Researching Translation Competence by PACTE Group (2017, s. 37) isimli eserde çeviri edinci şu şema ile açıklanır:

5 Bu ölçeğin geçerlilik analizleri bu çalışma dâhilinde yapılmıştır.

6 "Zengin noktalar" (Yıldız, 2016, s. 140) yerine "tuzaklar içeren metin(ler)" karşılığı önerilmektedir. 


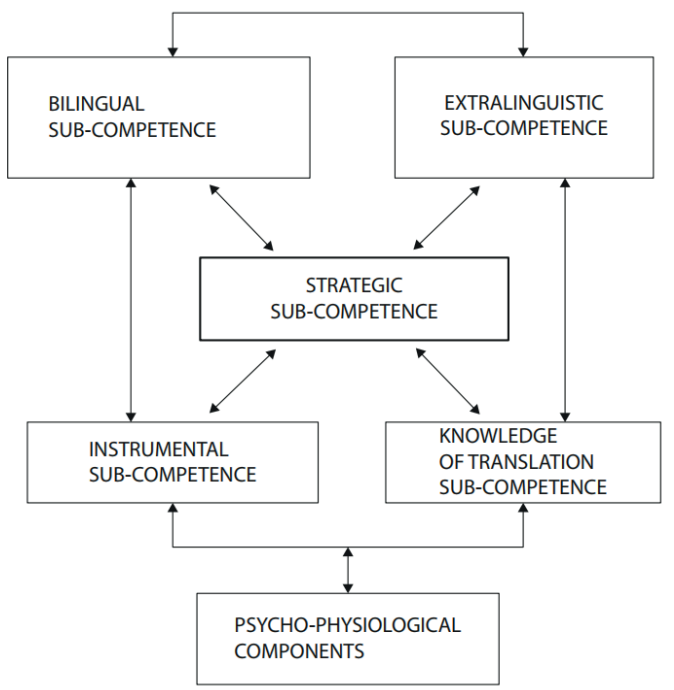

Şekil 1: Çeviri Edinci Modeli

Yukarıdaki şekilde görüldüğü gibi çeviri edinci iki dillilik bileşeni, dil dışı bileşen, stratejik bileşen, araçsal bileşen, çeviri bilgisi bileşenlerinin karşılıklı etkileşimine dayalıdır ve bu etkileşimler psiko-fizyolojik bileşenlerle olan ilişkiye etki eder.

\section{1. Çeviri Bilgisi Alt Edinci}

"Çeviri bilgisi alt edinci" (Hurtado Albir 2017, s. 39-40) çeviri ve çevirmenlik konusunda örtük veya açık bildirimsel bilgiye sahip olmayı gerektirir. Uzman bir çevirmen, çevirinin nasıl oluşturulduğunu, çeviri birimlerinin ne olduğunu, yararlanabileceği yöntemleri ve problem türlerini tanır. Mesleki gereklilikler konusunda bilgilidir. Özellikle çevirinin ne olduğu ve nasıl yapıldığı hakkında derinlikli bilgi sahibi olması beklenir. Bu nedenle de akademik çeviri eğitimi kapsamında öğrencilerde çeviri bilgisi alt edincinin oluşması için çevirinin ilkeleri konusunda öğrencilerde bir farkındalığın geliştirilmesi hedeflenir. Bu farkındalık sayesinde çeviri sürecinde izlenecek yola ilişkin alınması gereken kararlar bilinçli bir şekilde belirlenebilir. Bu kapsamda çeviri anlayışı, çevirinin ne olduğu, amacının ne olduğu, nasıl yapılabileceği, hangi zorlukları barındırdığı konuları çerçevesinde çeviri bilgisi alt edincinin bir unsuru olarak diğer alt edinçlerle birlikte bir etkileşim oluşturur. Çeviri anlayışı aynı zamanda çeviri yapabilmek için izlenecek yol ve işlemleri tasarlayan çerçeve için gerekli bilgi birikimidir. Öğrencilerde çeviri yaklaşımının geliştirilmesi, öğrencinin çeviri edincinin gelişimi açısından da son derece önemlidir ve bu nedenle özellikle akademik çeviri eğitiminin ilk evrelerinde dikkate alınması gereken bir unsurdur. 


\section{2. Çeviri Anlayışını Etkileyen Etmenler}

Etkin ve yerinde kararlar alarak bütüncül bir yaklaşımla çeviri yapması beklenen çevirmen adaylarının çeviri anlayışları kuşkusuz üniversitede aldıkları eğitim süresince müfredatlarda yer alan çeşitli derslerle desteklenir. Ancak Mütercim-Tercümanlık Bölümü öğrencilerinde ve dil puan türünden öğrenci alan diğer bölümlere gelen öğrencilerde çeviri edincini etkileyen olumlu ve olumsuz etmenler vardır. Söz gelimi dil puan türünden sınava hazırlanan öğrencilerde yabancı dil bilgisini geliştirmek adına çeşitli çalışmalar yaparken dil bilinci, dil duyarlılığı ve dilbilgisi de gelişmektedir. Öğrenciler dilin kuralları ve inceliklerini öğrenir. Farkındalığı artan bir öğrencinin çözümleme yeteneği ve bunlara bağlı olarak çeviri edinimi kolaylaşır. Öte yandan çeviri edincini olumsuz etkileyen etmenler de vardır. Bu olumsuz etmenler arasında özellikle çeviri anlayışını etkileyen ve çeviri bilgisi alt edincini ilgilendiren bilgilere ilişkin öğrencinin benimsediği ön kabuller çeviri edinci açısından önemlidir.

Konuyla ilgili araştırmalarda yükseköğretim kurumlarında görev alan akademisyenlerin çeviri derslerine yeni başlayan öğrencilere ilişkin gözlemleri dikkat çekicidir. Örneğin akademik çeviri eğitimi kapsamında bir uygulama örneği sunan Araboğlu (2018, s. 307) araştırmasında öğretim elemanlarının karşılaştığı ortak bir sorundan ve öğrencilerin "çeviriye karşı çekinceli bir yaklaşımları" olduğundan söz etmektedir. Parlak (2003, s. 57) ise bir çekinceden ziyade yerleşmiş bir tavrı eleştirmektedir: "[ö]ğrencilerin ilk yıllarda hazır reçeteler istemeleri"nden, "yakıcı 'kural' gereksinimleri”nden ve "bir metnin doğru tek bir çevirisi olabileceğine duydukları 'sarsılmaz' inanç"tan bahsetmektedir. Araştırmacının dikkat çektiği bu davranış biçimi, öğrencilerin üzerinde düşünmeden çeviri ile ilgili benimsedikleri ön kabuller açısından önemli bir göstergedir. Benzer şekilde İnce (1998) "Çeviri Eğitimine Nereden Başlıyoruz?" isimli çalışmasında ön koşullanmışlıkların çeviri alışkanlıklarına etki ettiğine ilişkin çarpıcı tespitlerde bulunmakta ve "[y]anlış koşullanmalarla geliştirilmiş anlayışlar" olarak tanımladığı ve çeviri yaklaşımını doğrudan ilgilendiren tutumun, Öğrenci Seçme ve Yerleştirme Merkezi'nin (ÖSYM) kullandığı yabancı dil seviyesini ölçme yönteminden kaynaklandığına işaret etmektedir. Bilindiği gibi, ÖSYM'nin hazırladığı üniversite sınavı, aday sayısının çok yüksek olması nedeniyle, değerlendirmelerin nesnel ve hızı olması adına çoktan seçmeli sınav tipindedir ve öğrenciler çeldirici seçenekler arasında doğru cevabı bulmayı amaçlarlar.7 Öğrenciye

7 Türkiye'de eğitim sisteminde kullanılan ölçme ve değerlendirme yöntemleri için bkz. Baykul/Turgut (2014), Çakan (2014) ve özellikle Tekin (2019). Çoktan seçmeli sınav tipinin öğrenciler üzerindeki olumsuz etkilerini inceleyen ve "test etkisi" veya "sınav etkisi" olarak tanımlanan olguya yönelik yapılan diğer güncel araştırmalar için bkz. Polat (2020, s. 153-154). 
uygulanan çoktan seçmeli testte "cevapları kesinlikle doğru, kesinlikle yanlış diye ayırmak mümkündür" (Tekin, 2019, s. 148). Bu nedenle öğrenci, tek bir seçeneğin doğru, diğerlerinin yanlış olduğu varsayımından hareket eder. Çeviri alanında hazırlanan sorular için de aynı durum geçerlidir: Çeldirici seçenekler arasından doğru cevabı bulmaya odaklanan ve sadece üniversiteye hazırlanma sürecinde değil, tüm eğitim yaşamı boyunca "tek doğru"nun izini süren öğrenciler çeviri sorularıyla da belirli bir davranış alışkanlığı edinirler.

Hazırlanan sorular, dilbilgisi ve kelime bilgisini ölçme üzerine kuruludur ve öğrencilerin önceki bölümde tanımlandığı biçimiyle çeviri edincini ölçmezler. Çeviri edinci yorumlamaya dayalı bir beceridir. Çeviri süreci buna bağlı karmaşık ve karar almayı gerektiren bir süreçtir. Ancak merkezi sınav sisteminde çeviri uygulaması yapılması istenen sorularda çeviri yöntemine ilişkin öğrencilerin sorgulama yapması gereksizdir, öğrencilerin bir karar alması, yorum yapması beklenmez, kaynak metinlerin dilbilgisel ve kelime bilgisi düzeyinde erek dile aktarımı istenir ve seçenekler içerisinde bu doğrultuda şıklar sunulur.

PACTE araştırma grubu çeviri yaklaşımını "devingen" (dynamic) ve "duruk" (static) olmak üzere ayrıştııı. Buna göre Nida (1964)'nın eşdeğerlik yaklaşımından yola çıkarak tanımladıkları devingen çeviride "metinsel, yorumsal, iletişimsel ve işlevsel" özellikler öne çıkarken, duruk çeviride dilbilimsel ve aslına uygun (düz anlam/yalın/ kelimesi kelimesine) (literal) bir yaklaşım benimsenir (Hurtado Albir 2017, s. 4 ve s. 74). Yukarıdaki tanımlardan yola çıkılacak olursa, ÖSYM tarafından öğrencilerin dil seviyesini belirleme amaçlı hazırlanan çeviri sorularının "duruk" bir yaklaşımla çevrilmesi gerektiği ve öğrencilerin de bu nedenle duruk çeviri yapmayı alışkanlık haline getirdiği açıktır. Öğrenciler çeviri soruları üzerinden duruk çevirinin, tek ve olması gereken "doğru" yaklaşım olduğunu ve çeviride izlenmesi gereken asıl yöntemin bu olduğunu çözdükleri her çeviri sorusuyla daha benimseyeceklerdir. Oysa müdahalelerde bulunmak metne sadık kalınmadığı anlamına gelmez aksine metnin özelliklerine göre, taşıdığı işleve göre bir çeviri oluşturmak metne ve yazarına duyulan saygının bir sonucudur (Neydim, 2006, s. 76).

Her ne kadar erek okur odaklı bir çeviri yaklaşımı benimseyen çevirmenlerin kaynak metne "ihanet" etmeyi göze alması tarih boyunca sıklıkla konu edilmiş olsa da ${ }^{8}$ literatürde "devingen" ve "duruk" kavramları dışında benzer ayrımları birçok bilim insanının çalışmasında da görmekteyiz, örneğin Nida (1964) biçimsel eşdeğerlik/devingen eşdeğerlik kavramlarını önerirken, Levý (1969) anti-illüzyonist/illüzyonist, Newmark (1988) anlamsal/iletişimsel, Nord (1989) belgesel/araçsal, Venuti (1995) yerlileştirme/

8 Çeviri tarihinde bu ayrımın gelişimini irdeleyen Yücel (2016) çalışmasıyla konuya ilişkin bir üst bakış sunmaktadır. 
yabancılaştırma, House (2010) açık/kapalı çeviriden söz etmektedir. Kavramların karşıladıkları anlamlar birebir örtüşmese de çeviri yönteminde iki farklı yolun mümkün olduğu gerçekliğini tarih boyunca birçok düşünür, çevirmen ve bilim insanı kanıtlamıştır. ${ }^{9}$

Ancak bu temel bilgi, üniversiteye hazırlanma sürecindeki öğrenci için önemli değildir çünkü kendisine yöneltilen soruların tümünde duruk bir yaklaşım beklentisi vardır, dolayısıyla yöntem ve uygulanabilecek işlemler konusunda farklı seçeneklerin bulunduğunu bilmez ve/veya önemsemez. Lörscher (2004, s. 299-300) uzman çevirmenlerle uzman olmayan çevirmenleri ayıran en önemli özelliğin uzman olmayanların biçimci bir yaklaşım sergilemeleri sonucu erek dilde metin normlarına uygun metin üretememelerini ve çeviri birimlerini belirlerken daha küçük birimleri temel almalarını saymaktadır. Daha küçük çeviri birimlerine yoğunlaşan aday çevirmenin bu nedenle bilişsel olarak metnin anlam bütünlüğüne odaklanamayacağını savunmaktadır. Öğrenci, sözcük birimlerine ve dizimsel biçimlere odaklanmaktadır. Farklı yaklaşımların mümkün olduğuna ve çevirmenin duruma göre bir yaklaşım benimsediğine ilişkin bir kanı bu biçimde oluşmaz, oluşamaz. Aksine, "doğru çevirinin" duruk bir çeviri yaklaşımı ile gerçekleştirilmesi gerektiği yönünde bir kanaat ve bir ön kabul gelişir.

\section{3. Ön Kabullerin Etkisinde Öğrenme}

Uzman çevirmenlerin çeviriye yaklaşımlarının çeviri sürecine yansımalarını inceleyen Rodrigues (2001, s. 7) araştırmasında çevirmenlerin doğrudan veya dolaylı olarak deneyimler üzerinden çeviri ile ilgili bazı ilkelere, beklentilere ve görüşlere vardıklarını yazmaktadır. Bu çıkarımlar öznel duyguların etkisinde biçimlenen ve inanılan olgulardır. Araştırmacı bu bağlamda şu örneği verir: eğer bir çevirmen bir metnin daima sözcüğü sözcüğüne çevrilmesi gerektiğine inanıyorsa, bu düşüncenin altında çeviriyle ilgili öznel çıkarımları yatmaktadır (2001, s. 7). Aday çevirmenlerin çeviriye ilişkin "çok naif" bir yaklaşım içinde oldukları yadsınamaz (Rodrigues, 2001, s. 13). Çeviri sürecine ve dolayısıyla çeviri ürüne doğrudan etki eden bu ön kabuller deneyimlerle örtüşmediği sürece sorgulanmaz ve alınan kararlar ve tutumların oluşumunda belirleyici bir rol oynar. Bunun yanında öncül bilgi ve deneyimlerle ilişkili olmayan bilgiler ancak bireyin kendisi için önemliyse öğrenilir. Çeviri bilgisi edinci, çeviri edinci ediniminde çok önemlidir, çeviri sürecine doğrudan etki eden çeviri bilgisi edincine yönelik yapılacak çalışmalarda bu önemin bilinci ile öğrencilerin konuya yaklaşımlarını sağlamak, ön kabullerini sorgulamalarına yardımcı olacaktır. Özellikle

9 Sadece çeviri yöntemleri için bu ikilik geçerli değildir. Dile bakış açısından da biçimci ve işlevci paradigma ayrımı yapılabilir (bkz. Aksan, 1993). 
aday çevirmenlerin akademik çeviri eğitimine başladığı ilk zamanlarda konuya dikkat çekmek, öğrencinin bu şekilde farkındalığını arttırmak, alışık olmadığı bağları kurmasına yardımcı olacak çarpıcı örnekler vermek, ileriki süreçte çok boyutlu düşünmesini ve erek metni oluştururken etkin çözümler bulmasını kolaylaştıracaktır.

\section{Anket Çalışması}

\subsection{Katılımcılar}

Tüm analizlerin ${ }^{10}$ IBM SPSS Statistics 25 programı kullanılarak yürütüldüğü anket çalışmasına, yaşları 19-42 aralığında $(M=21.16, S S=2.88)$ toplam 63 kadın ve 29 erkek, toplam 92 kişi katılmıştır ${ }^{11}$. ÖSYM sınav tipini henüz unutmamış olan, henüz çeviriye dair ön kabulleri taze olan bu denek grubundaki katılımcıların 47'si (\%53) Ege Üniversitesi Alman Dili ve Edebiyatı Bölümünde, 42'si (\%47) Ege Üniversitesi Almanca Mütercim Tercümanlık Bölümünde okumaktadır. Sadece 5 öğrenci (\%5) Türkçe'yi anadili olarak görmemektedir.

Katılımcıların dağılımı şu şekildedir: Alman Dili ve Edebiyatı Hazırlık Sınıfı Öğrencileri (ADE_H Grubu) 19 kişi, Alman Dili ve Edebiyatı Birinci Sınıf Öğrencileri (ADE_1 Grubu) 31 kişi, Almanca Mütercim-Tercümanlık Hazırlık Sınıfı Öğrencileri (AMT_H Grubu) 15 kişi ve Almanca Mütercim-Tercümanlık Birinci Sınıf Öğrencileri (AMT_1 Grubu) 27 kişi.

Anket sonuçlarına göre katılımcılardan 75 (\%82) kişi ileride çevirmen olarak çalışabileceğini dile getirmiştir. Mütercim-Tercümanlık Bölümü öğrencileri, Alman Dili ve Edebiyatı Bölümü öğrencilerine göre, alacakları eğitimin çevirmen olmak için daha yeterli olacağına inanmaktadırlar. Ancak Alman Dili ve Edebiyatı öğrencileri ileride çevirmen olmayı Almanca Mütercim Tercümanlık Bölümü öğrencilerine göre daha çok düşünmektedirler. Alman Dili ve Edebiyatı Bölümü'nde eğitim gören katılımcılardan 37'si (\%74) alacakları eğitimin çevirmen olarak çalışmak için yeterli olduğunu belirtmektedir. Bunun gerekçeleri incelendiğinde, öğrencilerin Alman Dili ve Edebiyatı Bölümü'nde uygulanan müfredatın bu edinci geliştirdiğini ve sunulan çeviri derslerinin de mesleki beceri ve deneyime katkısı olduğunu ifade ettikleri görülmektedir.

10 "Çeviri Anlayışının Çeviri Edincine Etkisi" başlıklı BAP projesinin sonuç raporundan yapılan değerlendirmelere ulaşılabilir.

11 Katılımc sayısının yapılacak analizler için uygunluğu G Power programı ile test edilmiştir (Faul et al. 2007). 
Üniversite sınavından önce, çeviri alanından gelecek sorular için özel olarak hazırlandığını belirten 45 kişi (\%49) bulunmaktadır. Üniversite sınavına nasıl hazırlandığını yazan öğrencilerin büyük bir çoğunluğu 27 kişi (\%29) "test çözerek" çalıştığını ve katılımcılardan sadece 7 kişi (\%8) üniversite sınavında çeviri alanından gelen soruların zor olduğunu belirtmiştir. "ÖSYM'nin hazırladığı çeviri soru türünden sorular hangi becerinizi ve/veya edinci ölçmektedir?" sorusuna öğrencilerin verdiği yanıtlar çok çeşitlidir: "dikkati ölçmektedir", "kelime ve gramer bilgisini ölçmektedir", "okuduğunu anlamayı ölçmektedir" diyen öğrencilerin yanı sıra "çeviri edincini ölçtüğünü" yazan öğrenciler de mevcuttur.

\subsection{Deney Tümceleri}

Anketin ikinci bölümünde öğrencilerin çeviri yaklaşımlarını belirlemek adına, çeviri birimi, çeviri sorunları, çeviri süreçleri (anlama, yeniden ifade etme, gözden geçirme), çeviri yöntemleri, kullanılan strateji ve teknikler, çeviri yönergesinin ve hedef okurun işlevi ve çeviri edinci anlayışı konularına ilişkin toplam 27 soru sorulmuştur. Soruların dağılımı şu şekildedir:

Tablo 1: Deney Tümcelerinin Sınıflandırılması

\begin{tabular}{|c|c|}
\hline Devingen & Duruk \\
\hline \multicolumn{2}{|c|}{ (1) Çeviri Birimi } \\
\hline- & Soru: 15,25 \\
\hline \multicolumn{2}{|c|}{ (2) Çeviri Sorunları } \\
\hline Soru: 14,17 & Soru: $9,12,26$ \\
\hline \multicolumn{2}{|c|}{$\begin{array}{c}\text { (3) Çeviri Süreçleri (Anlama, Yeniden Ifade Etme } \\
\text { Gözden Geçirme) }\end{array}$} \\
\hline Soru: 1, 19 & Soru: $7,13,18$ \\
\hline \multicolumn{2}{|c|}{ (4) Çeviri Yöntemleri } \\
\hline Soru: 10,23 & Soru: 4, 11 \\
\hline \multicolumn{2}{|c|}{ (5) Kullanılan Strateji ve Teknikler } \\
\hline Soru: 8,27 & Soru: $5,16,22$ \\
\hline \multicolumn{2}{|c|}{ (6) Çeviri Yönergesinin ve Hedef Okurun İşlevi } \\
\hline Soru: 3, 6, 21 & Soru: 24 \\
\hline \multicolumn{2}{|c|}{ (7) Çeviri ve Çeviri Edinci Anlayışı } \\
\hline Soru: 20 & Soru: 2 \\
\hline 12 Soru & 15 Soru \\
\hline \multicolumn{2}{|c|}{ Toplam: 27 Soru } \\
\hline
\end{tabular}


$\mathrm{Bu}$ soruların arasında nitelik durumları birbirine büsbütün aykırı olan zıt ikililer belirlenmiştir. Karşıt anlam taşıyan tümceler şu şekildedir:

Tablo 2: Zıt Ikili Oluşturan Deney Tümceleri

\begin{tabular}{|c|c|}
\hline Devingen & Duruk \\
\hline \multicolumn{2}{|c|}{ Çeviri yönergesinin ve hedef okurun işlevi } \\
\hline Soru: 3 & Soru: 24 \\
\hline \multicolumn{2}{|c|}{ Çeviri Yöntemleri } \\
\hline Soru: 10 & Soru: 4 \\
\hline \multicolumn{2}{|c|}{ Çeviri Yöntemleri } \\
\hline Soru: 23 & Soru: 11 \\
\hline \multicolumn{2}{|c|}{ Çeviri Yönergesinin ve Hedef Okurun İşlevi } \\
\hline Soru: 14 & Soru: 5 \\
\hline \multicolumn{2}{|c|}{ Çeviri Yönergesinin ve Hedef Okurun İşlevi } \\
\hline Soru: 27 & Soru: 16 \\
\hline
\end{tabular}

Yapılan inceleme sonucunda Almanca Mütercim-Tercümanlık Bölümü öğrencilerinin çeviri yaklaşımının devingen, Alman Dili ve Edebiyatı öğrencilerinin duruk olduğu gözlemlenmiştir. Alman Dili ve Edebiyatı öğrencilerinin devingen ve duruk çeviri tutarlılıkları $^{12}$ daha yüksektir.

\section{3. Çeviri Uygulaması}

Anketin üçüncü kısmında öğrencilerin bir çeviri uygulaması yapmaları istenmiştir. Öğrencilerin kuramsal olarak sahip oldukları bilginin yöntemlerine yansıyıp yansımadığını görmek adına yapılan bu çalışmada öğrencilere seçenek sunulmamış, serbest cevap (Tekin, 2019, s. 111) vermeleri istenmiştir.

Hazırlık sınıfı öğrencilerinin dil edinçlerinin A2.2 düzeyinde, birinci sınıf öğrencilerinin de Avrupa Ortak Dil Çerçevesi Seviye Sınıflandırmasına göre B1 düzeyinde olması beklenen katılımcılardan ADE_H, AMT_H ve ADE_1 öğrencileri eğitimleri kapsamında çeviriye yönelik özel bir ders almamıştır. AMT_1 öğrencileri ise bahar ve güz yarıyılında olmak üzere iki dönem "Translatorische Basiskompetenz", güz döneminde "Text und Übersetzung" ve bahar döneminde "Übersetzungsorientierte Textanalyse" dersleri olmak

12 Çeviri tutarlılığı ile kast edilen, çeviri sürecinde çevirmenin benimsediği yaklaşıma ilişkin gösterdiği tutarlılıktır. 
üzere çeviri edinçlerini geliştirmeye yönelik dört ayrı derse devam etmişlerdir. Sunulan metin, öğrencilerin dil düzeylerine uygun bir şekilde oluşturulmuş ve çeviri edinçlerini ölçmeye yönelik seçenekler sunacak şekilde tasarlanmıştır. Nord'un "rich points" olarak tanımladığı tuzaklar içeren üç cümle üzerinden katılımcıların çeviri edinçleri ölçülmüş ve öğrencinin çeviri yönteminin duruk veya devingen olup olmadığı sınanabilmiştir. Kabul edilebilirlik skalası üzerinden yapılan bu ölçümle katılımcıların çeviri anlayışı ve uygulamada benimsenen yaklaşımı değerlendirilebilmiştir. Anketin üçüncü bölümünde bu çerçevede, öğrencinin çeviri bilgisi alt edinci ölçülmüş ve hangi güdümlerin başarıyla kullanıldığı ve hangilerinde başarısız kalındığı gösterilmiştir.

\subsection{Verilerin Çözümlenmesi}

Demografik değişkenler ile çeviri bilgisi edinci ve tutarlılığı arasındaki ilişki korelasyonel analiz ile incelenmiştir. Katılımcının uygulama sırasındaki becerileri ile çeviri edinci arasındaki ilişki de yine korelasyonel analiz ile incelenerek ve demografikler kontrol edilerek hiyerarşik regresyon ile son aşama tamamlanmıştır.

Katılımcıların kişisel bilgilerini öğrenmeye yönelik anketin birinci bölümünde sorulan sorulara istinaden şu verilere ulaşılmıştır:

Çeviri bilgisi edinci ile demografik değişkenler incelendiğinde, erkek katılımcıların çeviri bilgisi edincinin daha yüksek olduğu görülmüştür. Almanca Mütercim- Tercümanlık Bölümü öğrencilerinin çeviri bilgisi edinci, Alman Dili ve Edebiyatı Bölümü öğrencilerine göre daha yüksektir. İleride çevirmen olmayı düşünen öğrencilerin ise çeviri bilgisi edinci daha düşüktür. Çeviri bilgisi edinci ve çeviri tutarlılığı arasında bir ilişki bulunamamıştır.

Çeviri uygulamasına yönelik yapılan araştırmada çevrilmesi istenen ilk cümlenin - "(1) Es war einmal eine Hanna oder Emma oder eine Mia - niemand weiß mehr ihren genauen Namen" - 74 katılımcı tarafından çevrildiği ve sadece 8 katılımcının devingen bir çeviri yaklaşımı benimsediği görülmüştür. 66 katılımcı (\%89) Hanna, Emma ve Mia isimlerini değiştirmeden erek metinlerini oluşturmuşlardır.

Çevrilmesi istenen ikinci cümlede ise - "(2) Komm, Rotkäppchen, ich habe dir eine Flasche Wein und ein Stück Kuchen in den Korb gepackt" - 74 katılımcıdan 53 katılımcı (\%72), yiyecek ve içecek olarak şarap ve keki tercih ederek duruk bir yaklaşımla çeviri yapmıştır. 
Uygulamada çevrilmesi istenen üçüncü cümle - "(3) Und, Rotkäppchen, denk daran, sieh die Großmutter an, wenn du sie begrüßt und guck nicht erst in alle Ecken herum" 68 öğrenci tarafından Türkçeye aktarılmıştır. 55 katılımcı (\%74) duruk bir yaklaşım benimsemiştir. Öğrencilerin büyük bir kısmı "büyükanneyi selamlarken ona bak” anlamına gelecek cümleler kurmuşlardır.

Çeviri tutarlılığına bakıldığında, ana dili Türkçe olmayan öğrencilerin çeviri bilgisi tutarlılığı daha yüksektir. Alman Dili ve Edebiyatı Bölümü öğrencilerinin çeviri tutarılıı̆ı, Almanca Mütercim-Tercümanlık Bölümü öğrencilerine göre daha yüksektir. İleride çevirmen olarak çalışmayı düşünen öğrencilerin tutarlılık skorlarının daha yüksek olduğu görülmüştür. Buna ek olarak, çeviri tutarlılığı ile katılımcıların uygulama sırasındaki becerileri arasında pozitif bir ilişki bulunmuştur. Bu bağlamda çeviri bilgisi edinci yerine çeviri tutarlılığı daha yüksek olan öğrencilerin bu tutarlılıkla benzer bir çeviri pratiği sergilediği görülmektedir.

Hiyerarşik regresyon analizi için ilk adımda demografik değişkenler, ikinci adımda çeviri tutarlılığı, üçüncü adımda ise çeviri pratiği eklenmiş ve çeviri bilgisi edincini yordayan değişkenler analiz edilmiştir. Modellerin üçü de anlamlı bulunmuştur. İlk modelde de ikinci modelde de yaş ve bölüm anlamlıdır. Çeviri tutarılığının anlamlı bir katkısı olmadığı görülmüştür. Son modelde ise yine yaş ve bölüm belirleyici olurken çeviri tutarlılığı ve çeviri pratikleri anlamlı değildir.

\section{Tartışma ve Sonuç}

Günümüzde çeviri yapan yapay zekâ ürünlerine ilgi her ne kadar artsa da duygusal ve yaratıcı zekâsı olan insan çevirmenlere olan gereksinim azalmamış, aksine gelişmelerle birlikte çevirmene ve çeviriye verilen değer artmış, çeviribilimsel araştırmalar hız kazanmıştır. Akademik çeviri eğitiminin günümüzdeki bilgi teknolojilerindeki gelişmelerle uyumlu hale gelmesi adına yapılan bilimsel çalışmaların da önem kazandığını görmekteyiz.

Çeviriye yönelik yazılımların ve bilgi teknolojilerinin geliştirilmesi, çevirmen yetkinliğini doğrudan ilgilendiren düzenlemelerin yapılabilmesi ve akademik çeviri eğitimin geliştirilmesi için ilgili parametreler doğru tanımlanmalıdır. Çeviri sürecini ve çeviri ürününü etkileyen etmenlerin ayrıntılı bir şekilde ortaya konması alanla ilgili bir gelişim sağlanabilmesi için önem taşır. 
Gerçekleştirdiğimiz çalışma çeviriyi doğrudan etkileyen belirli yöntemlere dayalı karar alma prosedürlerine ışık tutmuş ve yazılı çeviri için gerekli çeviri edincine odaklanmıştır. Belirli yöntemlere dayalı karar alabilme ve alınan kararları uygulamaya koyabilme yetisi çeviri edincine bağlıdır; duruma göre etkin ve yerinde kararlar alarak bütüncül bir yaklaşımla çeviri yapabilmek ancak çeviri edinci sayesinde mümkündür. Yapılan çalışma ile özellikle çeviri edincinin bir alt edinci olan çeviri bilgisi alt edinci ediniminin akademik çeviri eğitiminde dikkate alınması gerektiği ve çeviri bilgisi alt edincini ilgilendiren bilgi ve becerileri geliştirmeye yönelik çalışmalara bir gereksinim olduğu ortaya konabilmiştir.

Çeviri bilgisi konusunda farkındalık geliştiren öğrenci çeviri sürecinde izlenebilecek yola ilişkin bilinçli kararlar alabilir. Özellikle çevirinin amacı, yöntem ve zorlukları ilgilendiren çeviri anlayışı, çeviri sürecini ve işlemleri doğrudan etkilemektedir. Bilhassa akademik çeviri eğitiminin ilk evrelerinde aday çevirmenlerin çeviri yaklaşımının geliştirilmesine yönelik çalışmaların yapılması önemli bir öneridir.

Eylem araştırması yöntemini kullandığımız araştırma kapsamında, akademik çeviri eğitiminde öğrencilerin seviyesini belirlemede yukarıda sıralanan gereksinimler doğrultusunda öğretim materyali olarak destekleyici amaçla kullanılabilecek bir ölçek geliştirilmiş ve bu ölçeğin geçerliliğini belirlemek adına Ege Üniversitesi Alman Dili ve Edebiyatı Bölümü ve Ege Üniversitesi Mütercim-Tercümanlık Bölümü öğrencileri üzerinde bir analiz yapılmıştır. Ölçeğin çevirmen adaylarının bilişsel süreçlerini etkileyen ön kabullerini sorgulama olanağı vermesi nedeniyle öğrencilerde ön kabullere dayalı bir çeviri anlayışı olup olmadığı araştırılmıştır. Üniversiteye hazırlanma sürecinde öğrencilerin aşina olduğu ve kaynak metinlerin dilbilgisel ve kelime bilgisi düzeyinde erek dile aktarımına dayalı olan test tiplerinin çeviri anlayışlarını etkilediği tespit edilmiş ve çeviri uygulamaları üzerindeki etkileri incelemeye alınmıştır. Öğrencilerin çeviride "duruk" yaklaşımın tek ve olması gereken yaklaşım olduğu yönünde bir ön kabul benimsedikleri ve bu nedenle uygulamada da duruk çeviri yapmayı alışkanlık haline getirdikleri görülmüştür.

Çalışma kapsamında ayrıca aday çevirmenlerin kaynak metinden uzaklaşma korkusunu tetikleyen ve sözlük kullanma eğilimini besleyen biçimci bir yaklaşım olan bu duruk yaklaşım nedeniyle erek dilde metin normlarına uygun metin üretemedikleri, uzman çevirmenlere göre daha küçük çeviri birimlerini temel aldıkları görülmüştür. Öğrencileri dizimsel biçimlere ve sözcük birimlerine odaklanmaya yönelten ve aday çevirmenlerde sıklıkla görülen bu tutum, metnin anlam bütünlüğüne de odaklanmaya engel olmaktadır. 
Çalışmada Almanca Mütercim-Tercümanlık Bölümü öğrencilerinin çeviri yaklaşımının Alman Dili ve Edebiyatı öğrencilerine göre daha devingen olduğu ve Alman Dili ve Edebiyatı öğrencilerinin devingen ve duruk çeviri tutarlılıklarının daha yüksek olduğu sonucuna varılmıştır. Almanca Mütercim-Tercümanlık Bölümü öğrencilerinin çeviri bilgisi edinci, Alman Dili ve Edebiyatı Bölümü öğrencilerine göre daha yüksek olsa da ileride çevirmen olmayı düşünen öğrencilerin çeviri bilgisi edincinin daha düşük olması ilginç bir veri oluşturmaktadır. Öğrenciler arasındaki farkın birinci sınıfta aldıkları derslerden kaynaklandığı düşünülmektedir. Alman Dili ve Edebiyatı öğrencilerinin mezun olduktan sonra çevirmen olarak çalışmayı Almanca Mütercim Tercümanlık Bölümü öğrencilerine göre daha çok istemeleri ve aldıkları eğitimin çevirmen olmak için yeterli olduğunu düşünmeleri çarpıcı bir bulgu olarak göze çarpmaktadır.

Almanca Mütercim-Tercümanlık/Çeviribilim, Alman Dili ve Edebiyatı ve Alman Dili Eğitimi bölümlerinde Almanca-Türkçe dil çiftine yönelik çeviri eğitimi veren öğretim elemanlarının derslerde kullanabileceği ve öğrencilerin ön kabullerini sorgulamaya da yarayan bu ölçek, çevirinin nasıl oluşturulduğu, çeviri birimlerinin ne olduğu, yararlanabilecek yöntemler, karşılaşılacak problem türleri ve mesleki gereklilikler konularını irdelemeye yardımcı, öğrenme sürecini etkin bir şekilde destekleyen bir öğrenme ve öğretme materyalidir. Özellikle akademik çeviri eğitiminin başında ölçeğin kullanılması, ankete ilişkin konuların öğrencilerle birlikte değerlendirilmesi ve tartışıması, daha önce zihninde oluşmuş modelleri sorgulama olanağı sağlayacağıdan öğrencinin farkındalığının artmasını, çok boyutlu düşünmesini ve erek metni oluştururken etkin çözümler bulmasını kolaylaştıracaktır. Bu nedenle dilbilgisel açıdan kolay metinlerden zor metinlere doğru çeviri alıştırmaları yapmak yerine çeviri bilgisi alt edincine yönelik temel bilgilerin verilmesi, tuzak içeren metinler üzerinden duruk ve devingen çeviri yaklaşımları arasındaki farkların irdelenmesi ve çalışma kapsamında oluşturulan anketin öğrencilere sunulmasının yararlı olacağına inanmaktayız. Ölçek üzerinden bir tartışma ortamının yaratılması konunun ayrıntılı bir şekilde ele alınabilmesine ve öğrencilerde bir içtepinin oluşturulmasına fırsat vererek öğrencilerin kendi yaklaşımlarını da sorgulamalarına fırsat tanıyacaktır.

İleride yapılacak çalışmalarda farklı örneklemler kullanılarak öğrencilerin gelişim seyrinin de izlenilebilmesini mümkün kılan ölçek konuya ilişkin anlamlı sonuçların elde edilmesini de sağlayacaktır. 
Teşekkür: Araştırmanın gerçekleşmesinde değerli görüş ve önerileriyle beni destekleyen Saniye Uysal Ünalan'a, Nihan Demiryay'a ve Simge Yılmaz'a teşekkür ederim, ayrıca anketin oluşturulma ve sonuçlarının değerlendirilme aşamasında emeği geçen İlknur Çoban'a teşekkürü bir borç bilirim.

Hakem Değerlendirmesi: Dış bağımsız.

Çıkar Çatışması: Yazar çıkar çatışması bildirmemiştir.

Finansal Destek: Bu araştırma, Ege Üniversitesi Bilimsel Araştırma Projeleri Koordinasyon Birimi tarafından desteklenmiştir.

Acknowledgements: I would like to thank Saniye Uysal Ünalan, Nihan Demiryay and Simge Yılmaz, who supported me with their valuable opinions and suggestions in the realization of the research, and I would also like to thank Illknur Çoban, who contributed to the creation and evaluation of the results of the survey.

Peer-review: Externally peer-reviewed.

Conflict of Interest: The author has no conflict of interest to declare.

Grant Support: This research was supported by Ege University Scientific Research Projects Coordination Unit.

\section{Kaynakça}

Akalın, R. (2016). Akademik Çeviri Eğitimi Açısından Çeviri Edinci Kavramı ve İçerimleri. Diyalog, 2, 56-65.

Akdağ, A. I. (2019). Translation knowledge and translation decisions of translator trainees. RumeliDE Dil ve Edebiyat Araştırmaları Dergisi, 14, 480-493.

Aksan, M. (1993). Dilbilimde İşlevci - Biçimci Yaklaşım. Dilbilim Araştırmaları Dergisi, 4, 189-200.

Alves, F., \& Gonçalves, J. L. V. R. (2007). Modelling translator's competence. Y. Gambier, M. Shlesinger \& R. Stolze (Yay. Haz.), Doubts and Directions in Translations Studies: Selected contributions from the EST Congress. Amsterdam: John Benjamins, 41-55.

Angelone, E. (2012). The place of screen recording in process-oriented translator training. Rivista Internazionale di Tecnica della Traduzione, 14, 41-55.

Araboğlu, A. (2018). Çeviri Sürecinde Kendi Kararlarını Verebilen Çeviri Öğrencilerine Yönelik Bir Uygulama Örneği. RumeliDE Dil ve Edebiyat Araştırmaları Dergisi Özel Sayı, 4, 307-315.

Birkan Baydan, E. (2013). Çeviri Eğitiminde Çeviri/ Çevirmenlik Edinci: Problem Çözme ve Karar Verme Konusunda bir Farkındalık Uygulaması. Çeviribilim Dergisi, 7, 103-125.

Çakan, M. (2014). Eğitim Sistemimizde Yaygın Olarak Kullanılan Test Türleri. S. Tekindal (Yay. Haz.), Eğitimde Ölçme ve Değerlendirme. Ankara: Pegem, 92-126.

Durukan, E. (2018). Çeviri Öğretimi. Hedef ve Ölçme. İstanbul: Hiper Yayın.

Durukan, E. ve Çelikay, K. (2018). Çeviri Edinci Kavramına Yönelik Kapsayıcı Bir Tanım Önerisi. Turkish Studies, 13(12), 161-176.

Esen-Eruz, S. (2008). Akademik Çeviri Eğitimi. İstanbul: Multilingual.

Eser, O. (2015). Çeviribilimde Edinç Araştırmaları. Ankara: Anı.

Faul, F., Erdfelder, E., Lang, A.-G., \& Buchner, A. (2007). G*Power 3: A flexible sta-tistical power analysis program for the social, behavioral, and biomedical sciences. Behavior Research Methods, 39(2), 175-191. 
Göpferich, S. (2009). Towards a model of translation competence and its acquisition: The longitudinal study TransComp. S. Göpferich, A. L. Jakobsen \& I. M. Mees (Yay. Haz.), Behind the mind: Methods, models and results in translation process research. Kopenhag: Samfundslitteratur, s. 11-37.

Haldan, A. (2021). Çeviri Eğitiminde Çeviri Edinci Geliştirme Alışkanlıkları. Çanakkale: Rating Academy.

House, J. (2010). Overt and covert translation. Y. Gambier \& L. van Doorslaer (Yay. Haz.), Handbook of translation studies 1. Amsterdam/ Philadelphia: Benjamins, s. 245-246.

Hurtado Albir, A. (2017). Translation and translation competence. A. Hurtado Albir (Yay. Haz.), Researching Translation Competence by PACTE Group. Amsterdam/ Philadelphia: Benjamins, 3-33.

Hurtado Albir, A., Galán-Mañas, A., Kuznik, A., Olalla-Soler, C., Rodríguez-Inés, P., \& Romero, L. (2020). Translation competence acquisition. Design and results of the PACTE group's experimental research. The Interpreter and Translator Trainer, 14(2), 95-233.

İnce, Ü. (1998). Çeviri Eğitimine Nereden Başlıyoruz? T. Kurultay ve İ. Birkandan (Yay. Haz.), Forum: Türkiye'de Çeviri Eğitimi. Nereden Nereye? 1. İstanbul: Sel, s. 83-87.

Korkmaz, İ. (2019). Teknik Çeviri Eğitiminde Terminoloji - Çeviri Edinci İlişkisi: Örnek Bir İnceleme. RumeliDE Dil ve Edebiyat Araştırmaları Dergisi, 15, 328-341.

Kurultay, T. (1998). Çeviri Eğitimi Neden Farklı Bir Eğitimdir? Çeviri Bölümlerinin Programlarında Yöntem Derslerinin Gerekliliği ve Uygulama Koşulları. 6. Germanistik Sempozyumu. Yaz. Haz. A. Kesin. Mersin: Mersin Üniversitesi Fen Edebiyat Fakültesi Yayınları, 309-323.

Levý, J. (1969). Die literarische Übersetzung: Theorie einer Kunstgattung. Frankfurt am Main/ Bonn: Athenäum. Lörscher, W. (2004). Der Übersetzungsprozeß: Probleme der Beschreibung und Erklärung. H. Kittel et al. (Yay. Haz.), Übersetzung-Translation-Traduction. Ein internationales Handbuch zur Übersetzungsforschung. Berlin, New York: De Gruyter, s. 294-301.

Newmark, P. (1988). A Textbook for Translation. New York/ London: Prentice Hall.

Neydim, N. (2006). Çeviri Çocuk Edebiyatı ve Çocuk Edebiyatı Çevirisi Üzerine Varlık Dergisi Temmuz 1186, 74-76.

Nida, E. A. (1964). Toward a Science of Translating. Leiden: E. J. Brill.

Nord, C. ([1988] 2003). Textanalyse und Übersetzen. Heidelberg: J. Groos Verlag.

Nord, C. (2006). Loyality and fidelity in specialized translation. Revista de Tradução Científica e Técnica, 4, $29-41$.

Nord, C. (2014). Hürden-Sprünge. Ein Plädoyer für mehr Mut beim Übersetzen. Berlin: BDÜ Fachverlag.

Öncü, M. T. (2016). Übersetzungskompetenz (Deutsch-Türkisch). İzmir: Ege Üniversitesi Basımevi.

PACTE (2000). Acquiring Translation Competence. Hypotheses and Methodological Problems of a Reseach Project.

A. Beeby, D. Ensinger \& M. Presas (Yay. Haz.), Investigating Translation. Amsterdam: John Benjamins, s. 99-106.

PACTE (2003). Building a translation competence model. F. Alves (Yay. Haz.), Triangulating Translation: Perspectives in Process Oriented Research. Amsterdam: John Benjamins, s. 43-66.

PACTE (2017). Researching Translation Competence by PACTE Group. Amsterdam/ Philadelphia: Benjamins.

Parlak, B. (2003). Türkiye'de Çeviri Eğitimi, Sorunlar ve Beklentiler. Erişim adresi: https://dergipark.org.tr/en/ download/article-file/13564 (erişim tarihi: 10.05.2021). 
Polat, M. (2020). Investigating the backwash effect of higher education exam (YGS) on university students' attitudes. International Journal of Psychology and Educational Studies, 7(3), 152-163.

Rodrigues, C. (2001). Überzeugungen im Übersetzungsprozess. Eine empirische Untersuchung mit Berufsübersetzern. Erişim adresi: http://webdoc.sub.gwdg.de/ebook/dissts/Bochum/Rodrigues2001.pdf (erişim tarihi: 20.05.2021).

Şevik, N./ Gündoğdu, M. (2018). Çeviri Eğitiminde Çevirmen Adayı Öğrencilerin Edinmesi Gereken Temel Becerilere Bir Üst Bakış. Ihlara Eğitim Araştırmaları Dergisi, 3(1), 78-89.

Tapan, N./ Kuruyazıcı, N. (2020). İstanbul Üniversitesi Almanca Bölümlerinin Kuruluşundan Günümüze Gelişim Süreci. Diyalog. Özel Sayı: 2020, 223-231. Erişim adresi: https://dergipark.org.tr/en/download/articlefile/1318085 (erişim tarihi: 10.05.2021).

Tekin, H. (2019). Eğitimde Ölçme ve Değerlendirme. Ankara: Yargı.

Venuti, L. (1995). The translator's invisibility: A history of translation. London/ New York: Routledge.

Yazıcı, M. (2007). Yazılı Çeviri Edinci. İstanbul: Multilingual.

Yıldııım, A. ve Şimşek, H. (2016). Sosyal Bilimlerde Nitel Araştırma Yöntemleri (10.bs). Ankara: Seçkin Yayıncılık.

Yıldız, M. (2016). Mütercim Tercümanlık Öğrencilerinin Özel Alan Çevirisi Kapsamında Yazılı Çeviri Edinçlerinin Ölçülmesi. Basılmamış doktora tezi. İstanbul Üniversitesi Sosyal Bilimler Enstitüsü. İstanbul.

Yücel, F. (2016). Çevirinin Tarihi. İstanbul: Çeviribilim.

Yükseköğretim Kurumları Sınavı Yabancı Dil Testi (YDT) Almanca. 28 Haziran 2020 Pazar. Erişim adresi: https:// www.osym.gov.tr/ykspdf/ydt_Almanca_yks_2020.pdf (erişim tarihi: 19.05.2021). 


\section{EK}

Çeviri Bilgisi Edinci Anketi

LÜTFEN BU DÖKÜMANI DİKKATL̇CE OKUMAK İÇİN ZAMAN AYIRINIZ

Sizi Doç. Dr. Nilgin TANIŞ POLAT tarafindan yürütülen "Çeviri Anlayışının Çeviri Edincine Etkisi" başlıkı araștırmaya davet ediyoruz. Bu araştırmaya katılıp katılmama karanıı vermeden önce, araştırmanın neden ve nasıl yapılacağını bilmeniz gerekmektedir. Bu nedenle bu formun okunup anlaşılması büyük önem taşımaktadır. Eğer anlayamadığınız ve sizin için açık olmayan şeyler varsa, ya da daha fazla bilgi isterseniz bize sorunuz.

Bu çalışmaya katılmak tamamen qönüllülük esasına dayanmaktadır. Çalışmaya katılmama veya katıldıktan sonra herhangi bir anda çalışmadan çıkma hakkında sahipsiniz. Çalıșmayı yanıtlamanız, araștırmaya katılım için onam verdiăiniz biçiminde yorumlanacaktır. Size verilen formlardaki soruları yanıtlarken kimsenin baskısı veya telkini altında olmayın. Bu formlardan elde edilecek kişisel bilgiler tamamen gizli tutulacak ve yalnızca araștırma amacı ile kullanılacaktır.

Öğrencilerin hazır bulunuşluluklarını|ve gelişimlerini takip etmek üzere çeviriye ilişkin bilgi, beceri ve tutumlarını ölçmeyi amaçlayan bu çalışma ile akademik çeviri eğitimine katkıda bulunmayı amaçlıyoruz. Araştırmanın yapılabilmesi için ankete katılmanız önemlidir. Lütfen bütūn maddeleri boş bırakmadan doldurunuz.

Yardımlarınız için şimdiden teşekkür ederim.

Doç. Dr. Nilgin TANIŞ POLAT

\section{Bölüm}

Adınızın ve soyadınızın ilk iki harflerinden ve cep telefonu numaranızın son iki hanesinden oluşan bir rumuz oluşturun ve aşağıya o rumuzu yazın. Örneğin; NiTAPO90. Bu rumuz kişisel bilgilerinizi saklı tutmamıza yardımcı olacaktır. Daha sonraki çalıșmalarımıza katılmak isterseniz yine bu rumuz sayesinde kişisel bilgileriniz gizli tutularak eşleştirme yapılabilecektir.

1. Rumuzunuz:

2. Cinsiyetiniz:

․ Kadin

口 Erkek

3. Doğum tarihiniz (Yıl Olarak):

4. Ana diliniz:

口 Türkçe

口 Diğer (Lütfen yazınız):

5. Öğrendiğiniz ilk yabancı dil:

6. Bildiğiniz diğer diller:

7. Eğitim aldığınız üniversite:

8. Eğitim aldığınız bölūm:

9. Kaçıncı sınıftasınız:
a Hazırlık
व 1
2 

ㅁ 3
ㅁ 4

10. Eğitim aldığınız bölüm, kaçıncı tercihinizdi?

11. Hangi bölümde öğrenim görmek isterdiniz?

12. Üniversite sınavinda çeviri alanından gelen sorular sizce zor muydu?
a Evet
a Hayir

13. Üniversite sınavından önce, çeviri alanından gelecek sorular için özel olarak hazırlandınız mı?
a Evet
a Hayır

14. Yanıtınız evet ise, nasıl hazırlandı̆̆ınızı tek bir cümle ile açıklayınız.

15. Sizce ÖsYM’nin hazırladığı çeviri soru türünden sorular hangi becerinizi ve/veya edinci ölçmektedir?

16. ileride çevirmen olarak çalışmayı düşünür müsünüz?
a Evet
a Hayir

17. Alacağınız eğitimin çevirmen olmanız için yeterli olacağını düşünūyor musunuz?
a Evet
a Hayir

18. Nedenini tek bir cümle ile açıklayınız. 


\section{Bölüm}

Aşağıdaki ifadelerle ilgili görüşlerinizi sizin için en uygun olanı işaretleyerek belirtiniz.

\begin{tabular}{|c|c|c|c|c|}
\hline & $\begin{array}{c}\text { Kesinlikle } \\
\text { katılmıyorum }\end{array}$ & Katılmıyorum & Katılıyorum & $\begin{array}{c}\text { Kesinlikle } \\
\text { katılıyorum }\end{array}$ \\
\hline $\begin{array}{l}\text { 1. Kaynak metni (orijinal metni) okurken metnin } \\
\text { nasıl çevrilmesi gerektiği hakkında da fikir } \\
\text { yürütmek gerekir. }\end{array}$ & 1 & 2 & 3 & 4 \\
\hline $\begin{array}{l}\text { 2. Sözcükler kaynak ve hedef dilde genelde birebir } \\
\text { örtüşmediğinden çeviride daima bir kayıp } \\
\text { olușur. }\end{array}$ & 1 & 2 & 3 & 4 \\
\hline $\begin{array}{l}\text { 3. Müşteri, çevirmenin metni nasıl çevirmesi } \\
\text { gerektiğini belirler. }\end{array}$ & 1 & 2 & 3 & 4 \\
\hline $\begin{array}{l}\text { 4. Her çevirinin amacı, biçim olarak kaynak metne } \\
\text { en yakın olanı üretmektir. }\end{array}$ & 1 & 2 & 3 & 4 \\
\hline $\begin{array}{l}\text { 5. Kapsamlı bir sözlük yardımıyla, çeviri } \\
\text { sorunlarının büyük bir kısmının üstesinden } \\
\text { gelinebilir. }\end{array}$ & 1 & 2 & 3 & 4 \\
\hline $\begin{array}{l}\text { 6. Bir metni çevirirken en önemli şey, hedef } \\
\text { okurun beklentisini karşılamaktır. }\end{array}$ & 1 & 2 & 3 & 4 \\
\hline $\begin{array}{l}\text { 7. Kaynak metni anlamak için en önemli şey, } \\
\text { sözcüklerle ilgili sorunların üstesinden } \\
\text { gelmektir. }\end{array}$ & 1 & 2 & 3 & 4 \\
\hline $\begin{array}{l}\text { 8. Kaynak metnin özellikleri, hedef dilde aynı } \\
\text { türdeki metnin özelliklerinden çok farklı ise } \\
\text { (örn. ticari yazışma, kullanma talimatı vb.) } \\
\text { hedef metinde uyarlama yapılır. }\end{array}$ & 1 & 2 & 3 & 4 \\
\hline $\begin{array}{l}\text { 9. Bir dilde her sözcüğü bilmeniz beklenemez, bu } \\
\text { nedenle kapsamlı iki dilli bir sözlüğe sahip } \\
\text { olmak iyi bir çeviriyi gūvence altına alır. }\end{array}$ & 1 & 2 & 3 & 4 \\
\hline $\begin{array}{l}\text { 10. Bir metin, hedef okurun kim olduğuna bağlı } \\
\text { olarak farklı şekillerde çevrilmelidir. }\end{array}$ & 1 & 2 & 3 & 4 \\
\hline $\begin{array}{l}\text { 11. Çevrilen tüm metinlerde kaynak metindeki } \\
\text { paragraflar korunmalı ve cümleler de hedef } \\
\text { metne aynı sıralama ile aktarılmalıdır. }\end{array}$ & 1 & 2 & 3 & 4 \\
\hline $\begin{array}{l}\text { 12. Çeviride en büyūk sorunu, kalıplaşmış sözcük } \\
\text { grupları (deyimler, atasözleri vb.) oluşturur. }\end{array}$ & 1 & 2 & 3 & 4 \\
\hline $\begin{array}{l}\text { 13. Çeviri yapmanın en iyi yolu, kaynak metindeki } \\
\text { sözcüklere ve cümlelere odaklanmak ve onları } \\
\text { hedef dilde yeniden üretmektir. }\end{array}$ & 1 & 2 & 3 & 4 \\
\hline $\begin{array}{l}\text { 14. Teknik bir metni çevirirken, en zor olan, } \\
\text { kavramları çevirmek değildir. }\end{array}$ & 1 & 2 & 3 & 4 \\
\hline $\begin{array}{l}\text { 15. Atasözleri, deyimler ve metaforlar hariç, bir } \\
\text { metni çevirmenin en iyi yolu daima sözcüğü } \\
\text { sözcüğüne çevirmektir. }\end{array}$ & 1 & 2 & 3 & 4 \\
\hline $\begin{array}{l}\text { 16. Bir sözcüguún veya bir ifadenin anlamını } \\
\text { bilmediğinde ilk yapman gereken, iki dilli bir } \\
\text { sözlükte anlamına bakmaktır. }\end{array}$ & 1 & 2 & 3 & 4 \\
\hline
\end{tabular}




\section{Bölüm}

Aşağıda yer alan „Kırmııı Başıkı Kız" masalına ilişkin metnin, Türkiye'de faaliyet gösteren bir yayınevi tarafından Uykudan Önce Çocuklara Okunabilecek Maspllar serisinde yayımlanabilmesi için, çevirmen olarak görevlendirilseydiniz, 1-3 ile numaralandırılan cümleleri nasıl çevirirdiniz?

\section{Rotkäppchen}

(1) Es war einmal eine Hanna oder Emma oder eine Mia - niemand weiß mehr ihren genauen Namen. Denn von allen wurde sie nur Rotkäppchen genannt. Jeder, der das Mädchen nur ansah, hatte es lieb, am allerliebsten aber hatte es seine Großmutter. Einmal schenkte sie dem Kind ein wunderschönes Käppchen aus rotem Samt. Das stand ihm so gut, dass es nichts Anderes mehr tragen wollte. Daher nannte man es von nun an nur noch Rotkäppchen.

Eines Tages sagte die Mutter: (2) „Komm, Rotkäppchen, ich habe dir eine Flasche Wein und ein Stück Kuchen in den Korb gepackt. Bringe dieses Körbchen bitte zur Großmutter hinaus. Sie ist krank und schwach und soll sich daran stärken. Mach dich auf, bevor es heiß wird. Und vor allem, weiche nicht vom Weg ab, sonst fallst du, die Flasche zerbricht, und die Großmutter hat nichts. (3) Und, Rotkäppchen, denk daran, sieh die Großmutter an, wenn du sie begrüßt und guck nicht erst in alle Ecken herum. ${ }^{.}$Rotkāppchen versprach: „Ich will schon alles gut machen. " Dann machte es sich auf den Weg.

1)

2)

3) 